\title{
Renewable energy production based on solar power and magnetic field prototype in Bangladesh
}

\author{
Ohirul Qays ${ }^{1}$, Farhana Yasmin ${ }^{2}$ \\ ${ }^{1}$ Department of Electrical and Electronic Engineering, Universiti Malaysia Sarawak (UNIMAS), Malaysia \\ ${ }^{2}$ Department of Mechanical and Manufacturing Enginerring, Universiti Malaysia Sarawak (UNIMAS), Malaysia
}

\begin{tabular}{l}
\hline Article Info \\
\hline Article history: \\
Received Jun 25, 2019 \\
Revised Sept 13, 2019 \\
Accepted Feb 19, 2020 \\
\hline
\end{tabular}

Keywords:

Floating generator

Load management

Renewable energy

Solar energy

Tidal power

\begin{abstract}
Though modern technology of new era is mostly dependent on power sector entirely, the current energy scenario is showing a serious negative effect for the last few decades. Comparatively, Bangladesh is facing a precarious effect because of the scarcity of fossil-fuel dissipation. To accomplish the power demand resolution, a new type of power generation is proposed in this research paper. Magnetic flux and solar irradiation is combined to get maximum power outcome. The PV panel supplies the maximum power in the peak solar radiation and terminates the energy stream at night time. However, the floating generator can supply its maximum creation day or night time according to the movement of water wave tendency. For this reason, a PV-floating Generator based integrated renewable energy scheme is inspected in this venture. The experimental result shows its real-world validation (Maximum 14.5 Watt output) comparing to conventional methods.
\end{abstract}

This is an open access article under the CC BY-SA license.

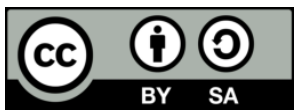

\section{Corresponding Author:}

Ohirul Qays,

Department of Electrical and Electronic Engineering,

Universiti Malaysia Sarawak (UNIMAS),

Jalan Datuk Mohammad Musa, 94300 Kota Samarahan, Sarawak, Malaysia.

Email: $18020101 @$ siswa.unimas.my

\section{INTRODUCTION}

Speedy evolution of inhabitants, urbanization and industrialization prompted energy outgoings remarkably in Bangladesh. Each capita for power expenditure (246 kWh) is lower comparing to another flourishing country e.g. the neighbor countries India $(480.5 \mathrm{kWh})$ and Pakistan $(456.2 \mathrm{kWh})[1,2]$ By 2021, Government of Bangladesh, intended to make available unbroken power supply to every people according to revealed in the power system master plan (PSMP) 2010. Nevertheless, Bangladesh can face dangerous power convergence scarcity in adjacent to upcome as per current assessment condition. It is estimated that by 2021, power necessity will upsurge up to $18,838 \mathrm{MW}$, and it may touch 33,708 MW nearly 2030 [3, 4].

On the other hand, renewable energy sources are found in a countryside and attained from the natural procedure with no inanition in the progression of application. Bangladesh is gratified with renewable energy sources e.g. biomass, wind, solar and small-scale hydropower energy as shown in Figure 1(a) [3,5]. Some procedures are executed to prompt renewable energy sources by the Government of Bangladesh. At present, many government, semi-government and non-government institutes are performing severally or unitedly to proclaim Renewable Energy Technology (RET) in every space of the countryside for different periods in a year. Sustainable and Renewable Energy Development Authority (SREDA) has introduced some projects to upgrade the revolution of Renewable Energy resources by Bangladesh government. Table 1 represents the targeted capacity for renewable energy projects according to SREDA [6]. To further improve the load management system, Bangladesh Power Development Board (BPDB) installed 
12,365 MW power generation capacity on June, 2016 (Figure 1(b)) for which different energy resources were contributed according to their availability [7].

Nonetheless, a huge amount of energy gap is notified between the maximum power generation and peak demand for last some years which is shown in Figure 2. To fix the power supply misbalancing, a new type of energy production is proposed in this paper. Solar PV and floating generator integrated renewable energy sources are experimented in Khulna University of Engineering and Technology (KUET), Bangladesh. Solar power application is introduced for the last 20 to 30 years in Bangladesh. However, the concept of buoyant power generator is completely new with respect to this country [8]. Rahman et al., [9] studied on the solar lane and floating solar energy collection to reduce the power demand and extra land requirements. For the optimistic effects of Bay of Bengal in Bangladesh, Fowze et al., [10] proposed 30MW wave energy generator installation which is initialized in Europe recently.

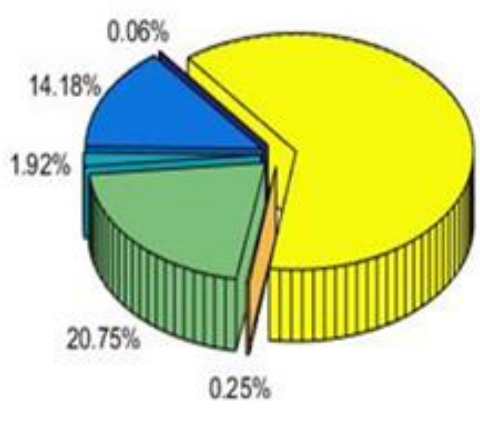

(a)

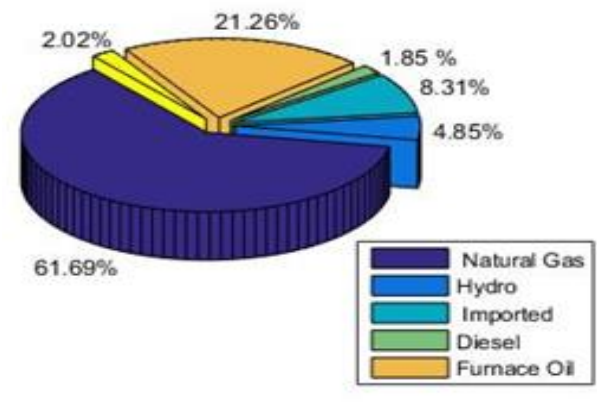

(b)

Figure 1. (a) Different renewable energy resources in Bangladesh, (b) installed generation capacity on June 2016 for $12,365 \mathrm{MW}$

Table 1. The targeted capacity for renewable energy according to SREDA [6]

\begin{tabular}{cccccccc}
\hline Technology & 2015 & 2016 & 2017 & 2018 & 2019 & 2020 & 2021 \\
\hline Solar & 75 & 336 & 422 & 237 & 195 & 203 & 208 \\
Wind & 0 & 20 & 250 & 350 & 350 & 200 & 200 \\
Biomass & 1 & 16 & 6 & 6 & 6 & 6 & 6 \\
Biogas & 1 & 1 & 1 & 1 & 1 & 1 & 1 \\
Hydro & 0 & 2 & 0 & 0 & 0 & 0 & 0 \\
Total (MW) & 77 & 375 & 681 & 594 & 552 & 410 & 415 \\
\hline
\end{tabular}

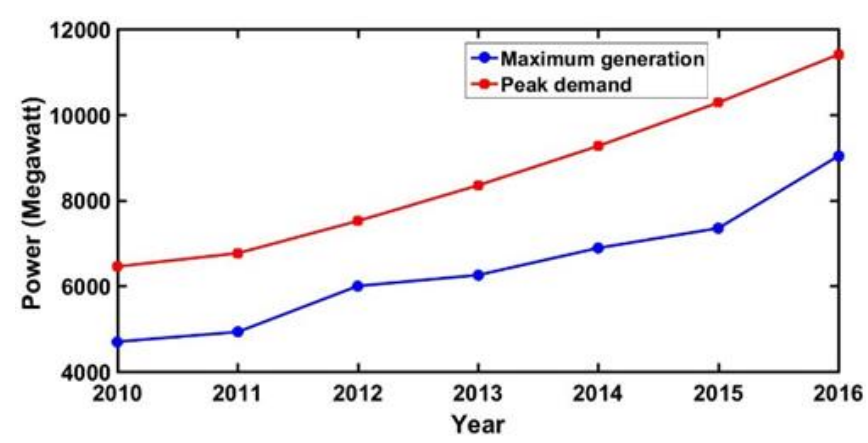

Figure 2. Comparison between maximum power generation and peak demand annually

Khan et al., [11] showed the comparison between present electricity generation cost and various wave energy harvester to prove the wave power advantageous feasibility on behalf of Bangladesh. Salimullah [12] analyzed the power vs wave height and wave period in Matlab software with respect to Bangladesh and designed a wave energy harnesser prototype experimentally. In case of $0.02 \mathrm{~m}$ wave height, 
they obtained 1.5volt result and recommended about Cox's bazar application (2.8m wave height). Consequently, the proceeding of the noble investigation is tried to boost in this paper. The rest of this research paper is arranged as follows: Section 2 deliberates the Solar-PV and floating generator working mechanism individually. The experimental result and discussion is mentioned in section 3 . In section 4, the conclusion of the entire appraisal is drawn

\section{METHODOLOGY}

\subsection{Solar energy}

Bangladesh partakes a enormous possibility of employing solar radiation owing to its environmental position. Average solar radiation for a year of several certain cities and islands in Bangladesh is undertaken in Figure 3(a) [13]. Therefore, IDCOL and Grammeen Shakti initiated the solar arrangement in 2003 and overall installed $150 \mathrm{MW}$ in 2013-2014 with $185.185 \%$ upsurge over the earlier year. Islam et al., [14] studied an appraisal on solar irrigation system on Bangladesh to improve the cost efficacy and reduce the extra pressure from grid connection. Das et al., [15] analyzed on PV/Diesel hybrid system on HOMER software and showed that the combined dispatch performs lower cost comparing to Load Following and Cyclic Charging techniques. Rahman [16] demonstrated a review on the supply and demand power generation from 1996-2010. They also deliberated about the battery storage application and public awareness to progress the production potentiality. For this reason solar PV application is intended in this experiment. The equivalent circuit model of PV module is shown in Figure 3(b).

The voltage-current characteristics of a photovoltaic solar cell can be identified from (1) to (3). Here, $I_{P H}$ is the photocurrent that depends on the cell's working temperature $T_{W}$ and solar insolation, $R_{S H}$ is shunt resistance, $R_{S}$ is series resistance, $q$ is the charge of electron, $K$ is Boltzmann's constant, $T_{R}$ is a reference cell temperature, $I_{R S}$ is the cell's reverse saturation current and $E_{G}$ is the energy band-gap of the semiconductor which is used for the photovoltaic module. The short-circuit current $I_{S C}$ is measured at $25^{\circ} \mathrm{C}, 1000 \mathrm{~W} / \mathrm{m}^{2}$.

$$
\begin{aligned}
& I=I_{P H}-I_{S}\left[\exp \left(q\left(V+I R_{S}\right) / K T_{W} A\right)-1\right]-\left(V+I R_{S}\right) / R_{S H} \\
& I_{P H}=\left[I_{S C}+K_{I}\left(T_{C}-T_{R}\right)\right] \lambda \\
& I_{S}=I_{R S}\left(T_{C}-T_{R E F}\right)^{3} \exp \left[q E_{G}\left(1 / T_{R E F}-1 / T_{C}\right) K A\right]
\end{aligned}
$$

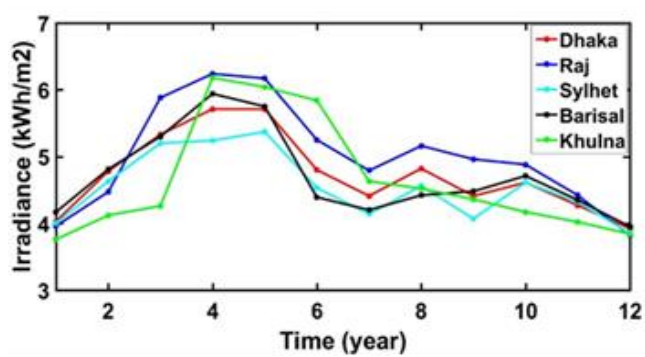

(a)

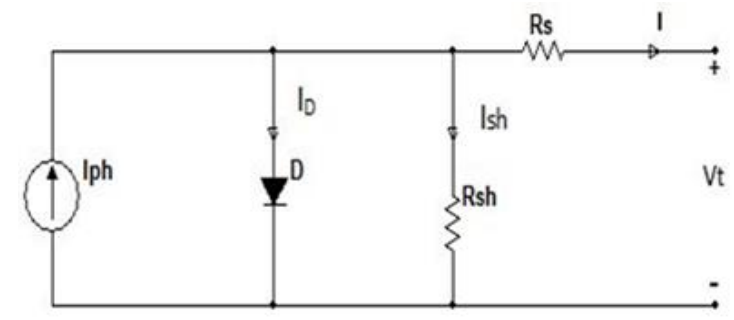

(b)

Figure 3. (a) Monthly average daily solar insolation at different cities, (b) PV equivalent circuit model

\subsection{Floating generator}

In recent years, Floating generator is a new type of energy harvester of water reservoir that consists of two parts: (a) floater and (b) energy converter [17, 18]. Gao et al., [19] investigated on a wave energy converter (WEC) for entire floating system to decline the mooring and maintenance delinquencies. To decrease the cost of the WEC, Lejerskog et al., [20] experimented on the buoy size and translator weight. Sanchez et al., [21] studied a comparison between floating and bottom-fixed Tidal Stream Turbines (TST) in NW Spain. They developed a 3D model and proved the improved performance of floating TST. Farrok et al., [22] analyzed the magnetic flux of the permanent magnet linear generator and proposed a floating generator to harvest energy from the oceanic wave. Samrat et al. [8] developed a system in MATLAB/SIMULINK software to approach the tidal energy potentiality with respect to Bangladesh. Kowser et al., [23] studied on Bay of Bengal and proposed a wave power collector to acquire the tidal power. 
Bangladesh contains $710 \mathrm{~km}$ coastal area with 2 8 $\mathrm{m}$ tidal height (rise and fall) for different regions as shown in Table 2 [24]. Especially in Khulna district, nearly $0.90 \mathrm{~m}$ to $3.5 \mathrm{~m}$ tidal height is discovered [25]. Consequently, to implement the tidal power a new type of floating generator is brought to light in this paper. The generator utilizes the wave motion for the movement of the magnet into a coil. Thus it produces electricity from the magnetic flux of the coil. The physical behavior of the floating generator can be described from (4).

Table 2. Tidal power generation from different locations in Bangladesh [24]

\begin{tabular}{ccc}
\hline Name of the station & Tidal range $(\mathrm{m})$ & Output power $(\mathrm{MW})$ \\
\hline Sandwip & 4.86 & 16.49 \\
Sadarghat (cht) & 3.70 & 9.56 \\
Mongla & 3.26 & 7.40 \\
Char Changa & 3.22 & 7.24 \\
Cox's Bazar & 2.70 & 5.09 \\
Teknaf & 2.54 & 4.51 \\
Hiron Point & 2.04 & 2.90 \\
Narayanganj & 2.4 & 5.43 \\
Khepupara & 5.69 & 30.53 \\
Potuakhali & 4.87 & 22.36 \\
\hline
\end{tabular}

$$
\left(W_{f l}+W_{a d}\right) \frac{d^{2} y}{d t^{2}}+\left(\alpha_{h}+\alpha_{g}\right) \frac{d y}{d t}+C_{F L} y=F_{w d}
$$

Where, $W_{f l}$ is mass of floater, $W_{a d}$ is the supplementary mass of water that is hastened above the floater, $\alpha_{g}$ is damping coefficient of the generator and $C_{F L} y$ is spring constant of the floating generator. The floater wave diffraction force $F_{w d}$ and the hydrodynamic damping coefficient $\alpha_{h}$ can be calculated from the wave period and wave amplitude. The produced energy from the floating generator is designed from (5) to (6).

$$
\begin{aligned}
& \left(W_{f l}+W_{a d}\right) \frac{d^{2} y}{d t^{2}}+C_{F L} y=0 \\
& E_{w}=\int_{0}^{T_{w}} P_{w} d t=\int_{0}^{T_{w}} \alpha_{h}\left(\frac{d y}{d t}\right)^{2} d t=\int_{0}^{T_{w}} \frac{F_{w}^{2}}{4 \alpha_{h}} d t=T_{w} \frac{F_{w}^{2} \max }{8 \alpha_{h}}
\end{aligned}
$$

\section{EXPERIMENTAL ANALYSIS AND DISCUSSION}

Faraday's Induction law is utilized to generate voltage from the moving magnets into the stationary coil. According to (7), peak voltage $\mathrm{V}$ will be increased along with the increment of cross sectional area A of the coil, rate of change of magnetic field $\mathrm{M}$ and number of turns of the stationary coil $\mathrm{N}$. In this experiment, about 20 pieces disk type permanent and strong 'rare earth' magnets (shown one of them in e.g. Neodymium magnets (Neodymium-Boron-Iron, Nd2Fe14B) was used to send out magnetic field constantly. Generally 22 SWG to $35 \mathrm{SWG}$ ranged wire is preferred to apply for the floating generator among which $28 \mathrm{SWG}$ wire was employed for the current experiment.

$$
\mathrm{V}=\mathrm{A} \times \mathrm{M} \times \mathrm{N}
$$

A 3 feet $x 3$ feet plastic board is employed as a glider for the arrangement of the system and all other instruments (coil, bread board, led lights, voltmeter, pipe, solar panel, etc.) are set up on the upper face of the board that is shown in Figure 4 and Figure 5 properly. From several experiments, it is noticed that the floating-PV arrangement can implement more power production efficiency than the overland PV arrangement and for this reason a SolarLand PV panel $(\mathrm{Pmax}=20 \mathrm{~W}$ Voc $=21.6 \mathrm{~V}, \mathrm{Imp}=1.16 \mathrm{~A}$ and Isc $=1.31 \mathrm{~A})$ is attached with the glider board technically [26, 27]. The voltage and power characteristics of 24 hours daily production is shown in Figure 6 and Figure 7 respectively.

Generally in the mid-time of a day, the solar radiation and tidal level movement is high, thus the power production increases. Conversely, in the night time or low tidal time, power generation becomes low. At this moment, a suitable storage system can supply the load demand. The LED lights were experimented as load to approach the novel work in the real world application. Practically $0.90 \mathrm{~W}$ to $14.5 \mathrm{~W}$ was obtained from this experiment In Figure 8, the entire system is drawn in a proper flowchart. 


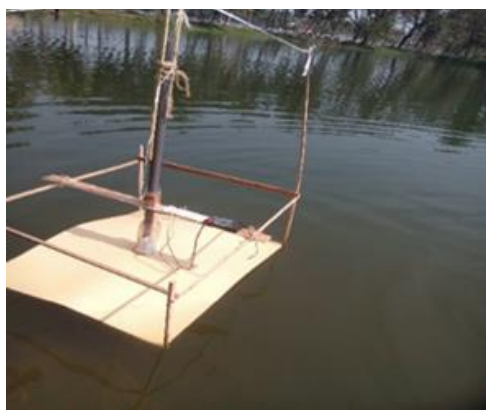

(a)

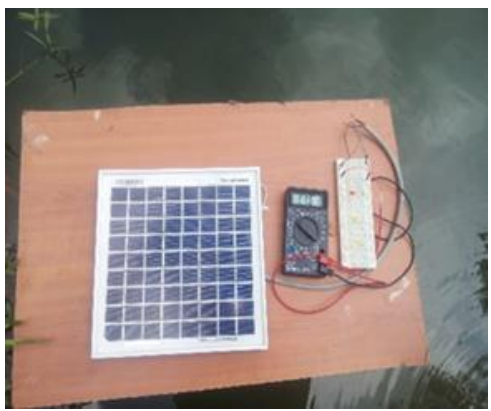

(b)

Figure 4. (a) Glider set up, (b) solar set up

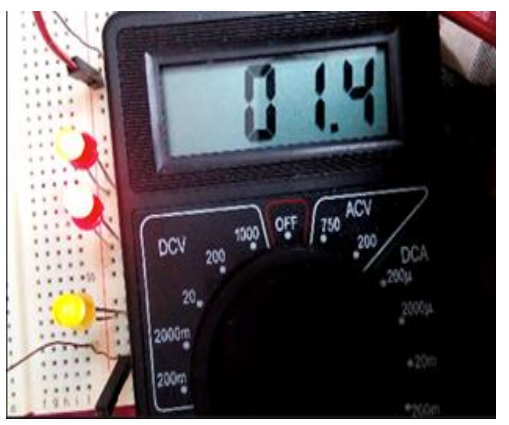

(a)

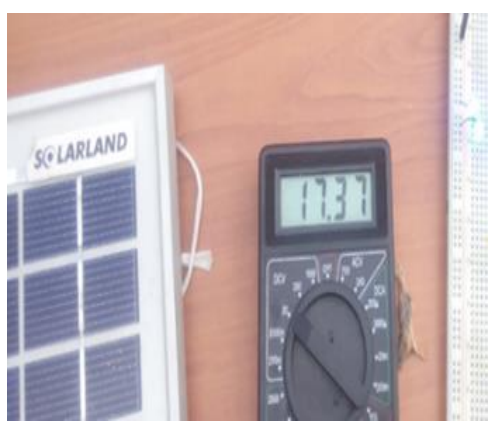

(b)

Figure 5. Experimental voltage from (a) floating generator, (b) solar panel
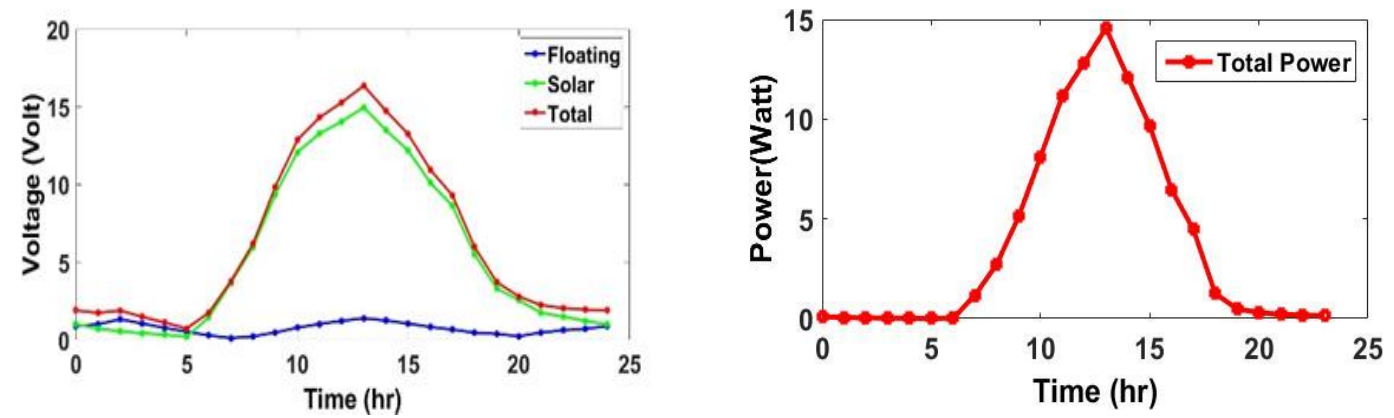

Figure 6. Resultant voltage from the entire system Figure 7. Resultant power from the entire system

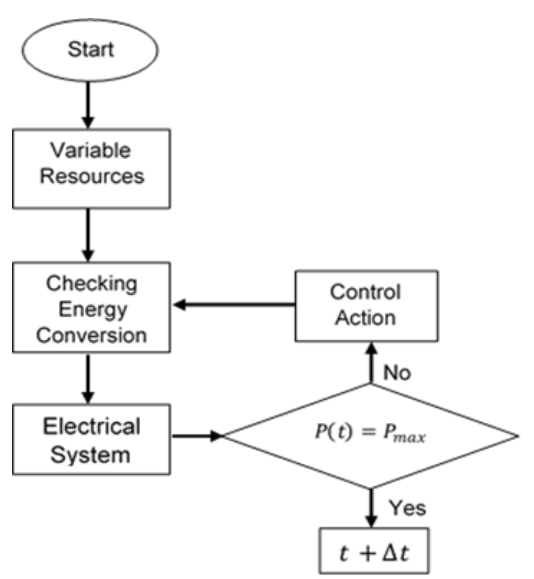

Figure 8. Flowchart of the proposed entire system 


\section{CONCLUSION}

A practical and cost effective system is experimented to mow energy from the water wave. The structure of the gleaner was planned to gather collected power from the solar panel and the floating generator. The solar panel and glider is floated on the water surface by means of moving the permanent magnests along with a spring and tensile rope which was bonded from one corner to another. Thus, the thresher is more malleable and operational to fruitage energy from the long or short waves of any water bank such as pond, river, sea etc. Though the two energy producers are connected in series to get more voltage and power endlessly, the producers can be attached in any series-parallel combination due to the requirement elucidation. At the noon time, 14.5 watt maximum power was obtained because of the peak solar radiation and high tidal factor. Integrating on the discoveries, the energy harvester is anticipated to be a resilient and encouraging applicant to mitigate the energy demand at this current duration specifically.

\section{ACKNOWLEDGEMENTS}

The authors would like to acknowledge the facilities supported by Khulna University of Enginerring \& Technology (KUET).

\section{REFERENCES}

[1] F. Ahmed, A. Quasem, A. Amin, M. Hasanuzzaman, and R. Saidur, "Alternative energy resources in Bangladesh and future prospect Alternative energy resources in Bangladesh and future prospect," Renewable and Sustainable Energy Reviews, vol. 25, pp. 698-707, September 2013.

[2] A. Kumar et al., "Solar energy for all? Understanding the successes and shortfalls through a critical comparative assessment of Bangladesh, Brazil, India, Mozambique, Sri Lanka and South Africa," Energy Research \& Social Science, vol. 48, pp. 166-176, February 2019

[3] P. K. Halder, N. Paul, M. U. H. Joardder, and M. Sarker, "Energy scarcity and potential of renewable energy in Bangladesh," Renewable and Sustainable Energy Reviews, vol. 51, pp. 1636-1649, November 2015.

[4] M. T. Islam, S. A. Shahir, T. M. I. Uddin, and A. Z. A. Saifullah, "Current energy scenario and future prospect of renewable energy in Bangladesh," Renewable and Sustainable Energy Reviews, vol. 39, pp. 1074-1088, November 2014.

[5] P. K. Halder, "Potential and economic feasibility of solar home systems implementation in Bangladesh," Renewable and Sustainable Energy Reviews, vol. 65, pp. 568-576, November 2016.

[6] Sustainable and Renewable Energy Development Authority (SREDA), "Ministry of Power, Energy and Mineral Resources (MPEMR)," 2019. [Online]. Available: https://mpemr.gov.bd/power/details/26.

[7] M. Rahman, "National Conservation Strategy," Aust. Plan., vol. 21, no. 4, pp. 108-108, 2010.

[8] N. H. Samrat, N. Mamun, S. M. Uddin, and A. Islam, "Case study: Tidal current energy potential in Bangladesh," 2013 International Conference on Informatics, Electronics and Vision (ICIEV), Dhaka, pp. 1-5, 2013.

[9] M. W. Rahman, M. S. Mahmud, R. Ahmed, M. S. Rahman, and M. Z. Arif, "Solar lanes and floating solar PV: New possibilities for source of energy generation in Bangladesh," 2017 Innovations in Power and Advanced Computing Technologies (i-PACT), Vellore, pp. 1-6, 2017.

[10] F. Fowze and S. Amir, "Ocean Wave Energy Based Power Plant for Sandwip, Bangladesh," 2nd International Conference on the Developments in Renewable Energy Technology (ICDRET 2012), Dhaka, pp. 1-5, 2012.

[11] R. J. Khan, S. Hossain, M. Mia, and D. H. Ahmed, "Energy Harvest from Water Wave - Bangladesh Prospect," Journal of Thermal Energy System, vol. 2, no. 3, pp. 1-11, 2017.

[12] S. M. Salimullah, M. M. E. Rafi, and M. R. I. Sheikh, "Prospects of Wave power in Bangladesh," American Journal of Engineering Research (AJER), vol. 3, no. 5, pp. 29-35, 2014.

[13] A. K. Biswas, B. Sajjakulnukit, and P. Rakkwamsuk, "Subsidy policy instruments for rapid growth of photovoltaic electricity generation in bangladesh,” Energy Procedia, vol. 52, pp. 68-76, 2014.

[14] M. R. Islam, P. C. Sarker, and S. K. Ghosh, "Prospect and advancement of solar irrigation in Bangladesh: A review," Renewable and Sustainable Energy Reviews, vol. 77, pp. 406-422, September 2017.

[15] B. K. Das and F. Zaman, "Performance analysis of a PV/Diesel hybrid system for a remote area in Bangladesh: Effects of dispatch strategies, batteries, and generator selection,” Energy, vol. 169, pp. 263-276, February 2019.

[16] M. Z. Rahman, "Multitude of progress and unmediated problems of solar PV in Bangladesh," Renewable and Sustainable Energy Reviews, vol. 16, no. 1, pp. 466-473, January 2012.

[17] G. Malara, A. Romolo, V. Fiamma, and F. Arena, "On the modelling of water column oscillations in U-OWC energy harvesters," Renewable Energy, vol. 101, pp. 964-972, February 2017.

[18] F. Maria, G. Malara, and F. Arena, "Performance optimization of a U-Oscillating-Water-Column wave energy harvester," Renewable Energy, vol. 99, pp. 1019-1028, December 2016.

[19] Y. Gao, S. Shao, H. Zou, M. Tang, H. Xu, and C. Tian, "A fully floating system for a wave energy converter with direct-driven linear generator," Energy, vol. 95, pp. 99-109, January 2016.

[20] R. Waters, M. Leijon, C. Boström, E. Lejerskog, and L. Hai, "Experimental results on power absorption from a wave energy converter at the Lysekil wave energy research site," Renewable Energy, vol. 77, pp. 9-14, May 2015. 
[21] M. Sánchez, R. Carballo, V. Ramos, and G. Iglesias, "Energy production from tidal currents in an estuary: A comparative study of floating and bottom-fixed turbines," Energy, vol. 77, pp. 802-811, December 2014.

[22] O. Farrok, M. R. Islam, and M. R. I. Sheikh, "Analysis of the Oceanic Wave Dynamics for Generation of Electrical Energy Using a Linear Generator," Journal Energy, vol. 2016, pp. 1-14, July 2016.

[23] M. A. Kowser, M. T. Islam, M. G. Uddin, T. B. Chakma, and M. Z. R. Chowdhury, "Feasibility study of ocean wave of the bay of bengal to generate electricity as a renewable energy with a proposed design of energy conversion system," International Journal of Renewable Energy Research, vol. 4, no. 2, pp. 445-452, May 2014.

[24] M. A. Hossain, M. Z. Hossain, M. M. Rahman, and M. A. Rahman, "Perspective and Challenge of Tidal Power in Bangladesh,” TELKOMNIKA, vol. 12, no. 11, pp. 1147-1150, 2014.

[25] M. Mutahara, J. F. Warner, A. E. J. Wals, M. S. A. Khan, and P. Wester, "Social learning for adaptive delta management: Tidal River Management in the Bangladesh Delta," International Journal of Water Resources Development, vol. 34, no. 6, pp. 923-943, 2018.

[26] P. E. Campana, L. Wästhage, W. Nookuea, Y. Tan, and J. Yan, "Optimization and assessment of floating and floating-tracking PV systems integrated in on- and off-grid hybrid energy systems," Solar Energy, vol. 177, pp. 782-795, January 2019.

[27] M. Perez, R. Perez, C. R. Ferguson, and J. Schlemmer, "Deploying effectively dispatchable PV on reservoirs: Comparing floating PV to other renewable technologies," Solar Energy, vol. 174, pp. 837-847, November 2018. 